\title{
Early Days of Tenascin-R Research: Two Approaches Discovered and Shed Light on Tenascin-R
}

\author{
Fritz G. Rathjen * and Russell Hodge \\ Department of Neuroscience, Max-Delbrück-Center for Molecular Medicine, Berlin, Germany
}

Keywords: tenascin-R, tenascin-C, human diseases, perineuronal nets, scaffolding

\section{THE PATH TO TENASCIN-R}

It has taken nearly 30 years. But finally, studies on cohorts of patients seem to be shedding some light on a protein that has been surfaced from time to time in the neurobiological literature. Tenascin-R, as it is now known, has proven a slippery quarry. That almost works as a pun, given the fact that in certain contexts, the molecule interferes with cell adhesion.

The protein was first identified in chicken and rodents in the late 1980s among a large number of molecules associated with axons. Significant efforts were being made to untangle the mysteries of axon growth, fasciculation and pathfinding (1). Monoclonal antibody approaches turned up a number of immunoglobulin (Ig)-like cell adhesion proteins (2) which, introduced into cell cultures, influenced the development of neurites (3). One of these was an IgCAM that interacted with the plasma membrane via covalently linked glycosylphosphatidylinositol; it was variously termed F11 protein, F3 or contactinnowadays contactin1 (4-9). Immunoaffinity isolates of contactin1 yielded a complex of at least two polypeptides. The major component was contactinl, at $130 \mathrm{kDa}$, and along with it a minor partner at about $170 \mathrm{kDa}$. Further biochemical and immunological experiments showed that the minor component was unrelated to the $130 \mathrm{kDa}$ contactin1, suggesting they had copurified $(5,10)$.

Antibodies to the $170 \mathrm{kDa}$ protein revealed that it was expressed in the developing nervous system, in a pattern partly overlapping with that of contactin 1 but spatially much more restricted. In the spinal cord, for example, it was found on the ventral side around motor neurons during embryonic development. This position suggested a name: restrictin (11). Independently, the same protein was discovered in the Schachner laboratory through different means: using the L2 monoclonal antibody directed to the L2/HNK-1 carbohydrate moiety (12), which captured several glycosylated proteins from neural tissues. These included, IgCAMs, tenascin-C (initially named J1-200/220) and tenascin-R (christened J1-160/180 or janusin by Schachner and her colleagues) (13).

\section{STRUCTURAL FEATURES AND THE TENASCIN FAMILY}

The experiments in chick and rodents had turned up homologs, as became clear through molecular cloning and sequencing of the chick and rat cDNAs. This showed that the components of restrictin and J1-160/180 represented the products of a common gene, and proteins were based on a set of structural motifs found in tenascin-C (14-18). These include an N-terminal cysteine-rich segment with three heptad repeats, followed by 4.5 EGF-like domains, nine fibronectin type III domains, and a C-terminal knob. The latter consists of a globular domain similar to the carboxyl terminal portion of the $\beta$ - and 
$\gamma$-chains of fibrinogen $(19,20)$. The $\mathrm{N}$-terminal cysteine-rich region serves as an oligomerization domain. Three heptad repeats of hydrophobic amino acids fold in an $\alpha$ helix and generate a triplestranded coiled coil to form a trimer which is stabilized by the surrounding cysteines. The related tenascin- $\mathrm{C}$ forms hexamers, which may also be the case for tenascin-R (21-23). So far, however, it has only been found as trimers, dimers and monomers in isolates of brain tissues (Figure 1) $(13,19)$. The Nterminal oligomerization domain of the pre-mRNA also contains one alternative splicing site; the $6^{\text {th }}$ fibronectin type III domain is also alternatively spliced. Based on these overall similarities, James Bristow and colleagues suggested renaming restrictin and J1-160/ 180 to tenascin-R; the proposal was promptly supported in a review article by Harold Erickson $(24,26)$. Subsequently the nomenclature has been universally adopted. Tenascin- $\mathrm{R}$ is the smallest member of the family, and the relationship of its sequence and those to TN-C, $\mathrm{TN}-\mathrm{X}, \mathrm{TN}-\mathrm{Y}$, and TN-W suggests that they arose from a primordial gene that most closely resembled TN-R $(26,27)$.

\section{TEASING OUT THE FIRST INTERACTION PARTNERS}

The complex, modular structure of tenascin-R clearly indicated a potential for diverse molecular interactions, most likely with other proteins on the cell surface. An early goal was to identify receptors that might interact with it and to map regions that could be essential for binding (28). In addition to contactin1, the partner responsible for its discovery, tenascin- $\mathrm{R}$ was found in complexes with the IgCAM members neurofascin and contactin2 (previously called axonin-1 or TAG1) (29). An additional cell surface receptor was found in a molecular interaction screen: the transmembrane protein CSPG5 (previously termed CALEB, or neuroglycan C). CSPG5 contains an EGF domain, an acidic stretch and chondroitin-sulfate chains, and it binds to the fibrinogen-like globular domain of tenascin-R (30-34).

More support for a physiological interaction between tenascin- $\mathrm{R}$ and contactin1 has come from molecular mapping studies. Immunoglobulin domains 2-4 of the latter molecule are sufficient for the interaction (35), and binding occurs to the second and third fibronectin type III domain of tenascin-R. This region is also important for interactions with neurofascin and contactin2 (29, 36). Tenascin-R interacts with other ECM proteins including fibronectin, $\beta 1$-integrins (37) and it binds with high affinity to phosphacan and a class of extracellular chondroitin sulfate proteoglycans collectively called lecticans (aggrecan, versican, brevican, and neurocan) (38-43). Later work demonstrated that tenascin- $\mathrm{R}$ also contains chondroitinsulfate chains of its own $(25,44)$.

Most of the interaction partners of tenascin- $\mathrm{R}$ have been defined primarily in vitro and through cell adhesion assays. Light microscopy work supports the colocalization of tenascin-R with

A

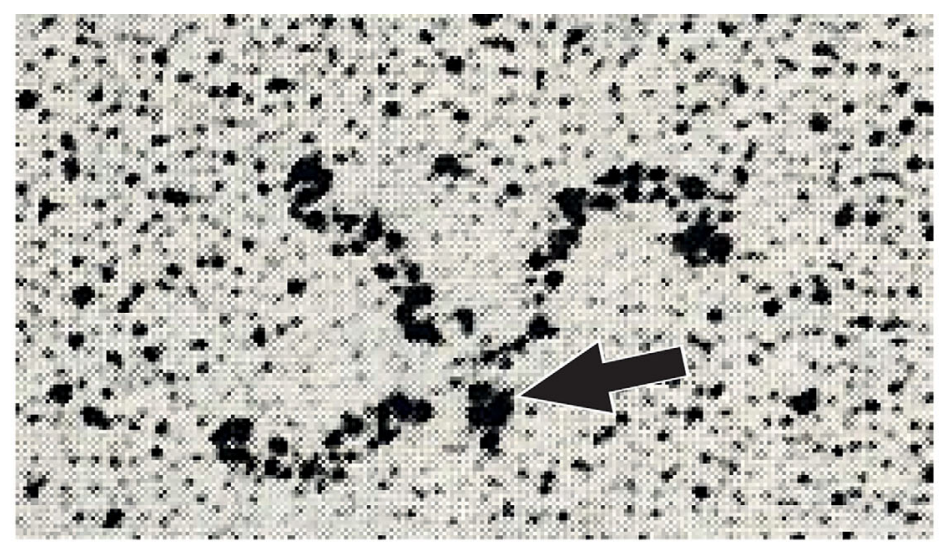

B Cysteine-rich EGF-like segment

FN III-like domains

FG-like

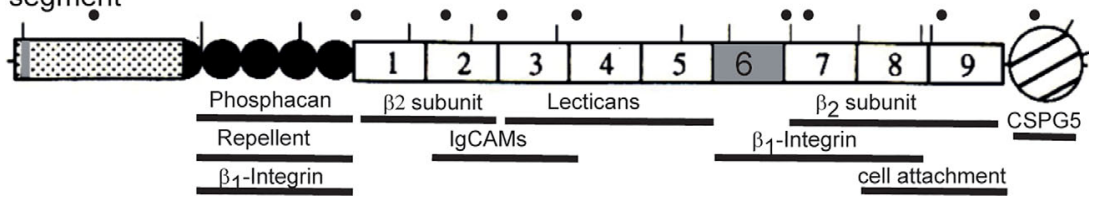

FIGURE 1 | (A) Rotary shadowing electron micrograph of tenascin-R purified from brains revealing a trimeric structure. Dimeric and monomeric but no hexameric forms were seen in these electron micrographs $(13,19)$. The TN-R polypeptide contains a single cysteine amino-terminal to the trimer-forming segment. This cysteine might connect two trimers into hexamers, the hexabrachion structure. It is therefore likely that TN-R might also form hexabrachions in tissues as found for tenascin-C (24). However, alternative splicing or proteolytical cleavage in the $\mathrm{N}$-terminal segment might affect multimer formation of tenascin-R $(19,25)$. The arrow points to the $\mathrm{N}$-terminal knob formed by a triple-stranded coiled coil. (B) Scheme of tenascin-R polypeptide. Lines above the scheme indicate putative $\mathrm{N}$-glycosylation sites of the chicken protein. Human disease mutations are marked by dots above the scheme and regions that bind to cell surface receptors, extracellular matrix proteins or indicate cellular activities are marked by bars below the scheme (please see text). Alternative splice sites of the pre-mRNA encoding TN-R are colored in grey. " 32 subunit" refers to the $\beta 2$-subunit of sodium channels. 
these proteins in some contexts, but for the most part, there is a lack of in vivo evidence of direct binding.

\section{THE SEARCH FOR BIOLOGICAL FUNCTIONS OF TENASCIN-R}

Cell culture experiments in the early days of tenascin- $\mathrm{R}$ research hinted at a number of putative functions through adhesion or neurite outgrowth assays. While many extracellular matrix glycoproteins are known to promote the attachment and spreading of cells, tenascin-R promotes only weak cell adhesion and does not affect cell spreading. For example, the $8^{\text {th }}$ to $9^{\text {th }}$ FNIII domains of tenascin- $\mathrm{R}$ serve as a weak cell attachment site for neural cells, which can be specifically blocked by mAb 23-14 (19). In some culture systems, tenascin-R even repels axons or inhibits their regeneration (45-47). A number of in vitro studies have also shown that tenascin- $\mathrm{R}$ modulates homophilic and heterophilic interactions between IgCAMs and extracellular matrix glycoproteins on neural cells $(6,29,36,39,46,48-54)$.

Obviously, the results of such in vitro studies have to be taken with a grain of salt, given that they may not accurately reflect the situation in the intact organism or provide true insights into the functions of tenascin- $\mathrm{R}$ in vivo. Here, further insights can come through studies of expression patterns. TN-R is apparently restricted to the central nervous system, but is absent from the peripheral-with the exception of transient expression on Schwann cells $(11,20,55-58)$. Around 2000 came a breakthrough with observations that tenascin- $\mathrm{R}$ is localized at perineuronal nets (59, 60). These structures were long known, having been described by several authors at the turn of the $20^{\text {th }}$ century. They surround groups of neurons and synapses on cell bodies primarily in the mature brain, comprising a specialized form of the extracellular matrix; constituents include hyaluronan, lecticans, and several other kinds of CSPGs $(61,62)$. Perineuronal nets attracted particular interest as brain structures that appear to be implicated in terminating the critical period for neuronal plasticity (63). Here a crucial function for tenascin-R began to emerge; it appears to be essential for the normal development of perineuronal nets. Tenascin-R-deficient mice exhibit an abnormal aggregation of perineuronal CSPGs $(59,64,65)$. In electron microscopy images, purified tenascin-R appears to crosslinks aggrecan complexes, which suggests that within the nets, tenascin- $\mathrm{R}$ might provide a molecular scaffolding for lecticans (40).

Knockouts of tenascin- $\mathrm{R}$ produced a number of phenotypes that might be traceable to this scaffolding function. At the cellular and functional levels, deficiencies lead to mild abnormalities in synaptic transmission and architecture $(66,67)$. These might arise through disruptions of structures involving lecticans or IgCAMs and CSPG5 $(32,33,68,69)$. Ultimately, the effects on the mature brain involve both structural and functional abnormalities. Consequently, tenascin- $\mathrm{R}$ deficient mice exhibit behavioral deficits such as severe impairments in locomotion and hippocampal-associated learning impairments (70).

Another interesting feature of tenascin-R emerged: in situ hybridization experiments revealed a dominant colocalization with oligodendrocytes during the period of active myelination $(20,71,72)$. In tenascin-R knockout mice, the nodes of Ranvier appear normal, but an analysis of compound action potential recordings from optic nerves revealed a decrease in the conduction velocity. A potential reason for this might be the lack of expression of tenascin-R on oligodendrocytes, which appears to be essential for their differentiation $(48,72)$; another could be that under normal conditions, the protein might associate with sodium channels to modulate their function (65, $73,74)$.

Very recently, a few studies on mouse knockouts combined with cell culture experiments have also shown that tenascin- $\mathrm{R}$ modulates the differentiation of neural stem cells during developmental and adult stages. In the olfactory bulb-a structure with a continuous flow of newborn neurons from the subventricular zone of the lateral ventricles-tenascin-R acts as a molecular cue that initiates a radial migration of neuroblasts toward the outer cell layers of the olfactory bulb. Consequently, an absence of tenascin- $\mathrm{R}$ affects the recruitment of neuroblasts in the olfactory bulb $(37,75,76)$. In the dentate gyrus of the hippocampus, tenascin- $\mathrm{R}$ is required for the fate determination of neural stem or progenitor cells. Its absence leads to an increase in the number of GABAergic neurons was increased $(77,78)$. In summary, these findings point to a role of tenascin- $R$ on neurogenesis.

\section{DISCUSSION}

\section{Insights From Human Disease Mutations}

Recently, an extensive exome sequencing study by a consortium identified 13 patients from eight unrelated families with biallelic variants in the human tenascin-R gene. Combined with two case studies already in the literature, this represents an important chance to investigate functions of the human form of the gene. So far, all of the patients affected have shared some common traits, particularly delays in motor development. The severity varies, ranging from spastic para- or tetraparesis, axial muscular hypotonia, to dyspraxia and transient opisthotonus (79-81). For example, compared to healthy counterparts, patients with the mutation take longer to develop unsupported sitting or standing. In line with these observations are data on mouse knockouts of tenascin-R or its cellular receptor CSPG5, which also exhibit motor deficits $(33,70)$. These problems in motor development in human patients can most likely be traced to the brain, given current evidence suggesting that tenascin-R expression is primarily restricted to the central nervous system $(11,19,20,55-58)$. And roughly half of the 13 patients revealed mild or moderately impaired cognitive development, including delayed language progression. Once again, there were differences in the degree to which patients were affected.

Overall, tenascin-R associated mutations led to health issues generally considered to be nonprogressive-which is in line with a pattern of expression in which tenascin- $\mathrm{R}$ predominantly appears during early brain development (79). MRI of patients' brains showed delayed myelination consistent with observations 
on tenascin- $\mathrm{R}$ mouse knockouts $(48,72)$ and, in a few cases, abnormalities in the structure of the corpus callosum. Both observations might be explained if humans follow the pattern observed in the mouse, where tenascin- $\mathrm{R}$ is expressed in developing oligodendrocytes $(20,71)$. The precise effects of the human missense mutations have yet to be determined: whether they affect the overall expression of tenascin- $\mathrm{R}$ or interactions with some of the interaction partners mentioned above. Some of these issues may be resolved with further binding assays and the generation of mouse models that replicate mutations specific to the in human patients. It would be particularly interesting to introduce mutations that interfere with molecular interactions of tenascin-R during the formation of perineuronal nets. If this impaired synaptic plasticity or disrupted the normal maturation and maintenance of neuronal circuits during critical periods of brain development, we would stand to learn much about the function of these complex intercellular structures.

As has been the case with many other diseases, the study of mutations in the human tenascin-R gene will likely prove to be a game changer, stimulating research into tenascin- $R$ and clarifying aspects of its functions that go beyond the molecule itself. Insights into its functions could redirect studies performed on the current mouse models. For example, tenascin- $\mathrm{R}$ might give scientists a handle on particular brain regions and their complex interactions at highly specific moments in development. The fact that human patients exhibit delays in motor development mean that this approach might serve as a wedge into this highly complex system within the central nervous system. It is interesting that in MRI examinations of the patients, the cerebellum appears normal (79). What would be the result of specifically inactivating tenascin- $\mathrm{R}$ in the mouse cerebellum? This might reveal whether the cerebellum plays a

\section{REFERENCES}

1. Tessier-Lavigne M, Goodman CS. The molecular biology of axon guidance. Sci (80- ) (1996) 274:1123-33. doi: 10.1126/science.274.5290.1123

2. Rajewsky K. The advent and rise of monoclonal antibodies. Nature (2019) 575:47-9. doi: 10.1038/d41586-019-02840-w

3. Sonderegger P, Rathjen FG. Regulation of axonal growth in the vertebrate nervous system by interactions between glycoproteins belonging to two subgroups of the immunoglobulin superfamily. J Cell Biol (1992) 119:138794. doi: $10.1083 /$ jcb.119.6.1387

4. Gennarini G, Durbec P, Boned A, Rougon G, Goridis C. Transfected F3/F11 neuronal cell surface protein mediates intercellular adhesion and promotes neurite outgrowth. Neuron (1991) 6:595-606. doi: 10.1016/0896-6273(91) 90062-5

5. Rathjen FG, Wolff JM, Frank R, Bonhoeffer F, Rutishauser U. Membrane glycoproteins involved in neurite fasciculation. J Cell Biol (1987) 104:343-53. doi: $10.1083 /$ jcb.104.2.343

6. Brümmendorf T, Wolff JM, Frank R, Rathjen FG. Neural cell recognition molecule F11: homology with fibronectin type III and immunoglobulin type C domains. Neuron (1989) 2:1351-61. doi: 10.1016/0896-6273(89)90073-1

7. Wolff JM, Brümmendorf T, Rathjen FG. Neural cell recognition molecule F11: Membrane interaction by covalently attached phosphatidylinositol. Biochem Biophys Res Commun (1989) 161:931-38. doi: 10.1016/0006-291X (89)92688-0

8. Ranscht B, Moss DJ, Thomas C. A neuronal surface glycoprotein associated with the cytoskeleton. J Cell Biol (1984) 99:1803-13. doi: 10.1083/ jcb.99.5.1803 role in the axial hypotonia or spasticity observed in patients with mutations in the tenascin- $\mathrm{R}$ gene-or whether these deficits are related to changes in perineuronal inhibition at the level of the spinal cord or basal ganglia. At the very least, this might offer a new perspective on how cells and structures in the developing nervous system intertwine at various levels to produce, on the one hand, a marvelously functioning organism-or on the other, a patient burdened by the symptoms of motor diseases.

\section{AUTHOR CONTRIBUTIONS}

All authors contributed to the article and approved the submitted version.

\section{FUNDING}

The work of the author was supported by the Max-DelbrückCenter and grant SFB665 by the DFG.

\section{ACKNOWLEDGMENTS}

The critical reading of Dr Dirk Montag (Magdeburg) is greatly acknowledged. The authors regret that not all publications on TN-R members could be cited in this article due to space limitations. FR thanks Dr Carmen Birchmeier (MDC, Berlin) for generous support and insightful discussions. FR is an emeritus professor, and $\mathrm{RH}$ is a science writer at the MDC.

9. Sanes JR, Zipursky SL. Synaptic Specificity, Recognition Molecules, and Assembly of Neural Circuits. Cell (2020) 181:536-56. doi: 10.1016/ j.cell.2020.04.008

10. Wolff JM, Rathjen FG, Frank R, Roth S. Biochemical characterization of polypeptide components involved in neurite fasciculation and elongation. Eur J Biochem (1987) 168:551-61. doi: 10.1111/j.1432-1033.1987.tb13453.x

11. Rathjen FG, Wolff JM, Chiquet-Ehrismann R. Restrictin: a chick neural extracellular matrix protein involved in cell attachment co-purifies with the cell recognition molecule F11. Development (1991) 113:151-64.

12. Kruse J, Keilhauer G, Faissner A, Timpl R, Schachner M. The J1 glycoproteina novel nervous system cell adhesion molecule of the L2/HNK-1 family. Nature (1985) 316:146-8. doi: 10.1038/316146a0

13. Pesheva P, Spiess E, Schachner M. J1-160 and J1-180 are oligodendrocytesecreted nonpermissive substrates for cell adhesion. J Cell Biol (1989) 109:1765-78. doi: 10.1083/jcb.109.4.1765

14. Spring J, Beck K, Chiquet-Ehrismann R. Two contrary functions of tenascin: dissection of the active sites by recombinant tenascin fragments. Cell (1989) 59:325-34. doi: 10.1016/0092-8674(89)90294-8

15. Jones FS, Hoffman S, Cunningham BA, Edelman GM. A detailed structural model of cytotactin: protein homologies, alternative RNA splicing, and binding regions. Proc Natl Acad Sci USA (1989) 86:1905-9. doi: 10.1073/pnas.86.6.1905

16. Chiquet M, Fambrough DM. Chick myotendinous antigen. I. A monoclonal antibody as a marker for tendon and muscle morphogenesis. J Cell Biol (1984) 98:1926-36. doi: 10.1083/jcb.98.6.1926

17. Chiquet M, Fambrough DM. Chick myotendinous antigen. II. A novel extracellular glycoprotein complex consisting of large disulfide-linked subunits. J Cell Biol (1984) 98:1937-46. doi: 10.1083/jcb.98.6.1937 
18. Grumet M, Hoffman S, Crossin KL, Edelman GM. Cytotactin, an extracellular matrix protein of neural and non-neural tissues that mediates glia-neuron interaction. Proc Natl Acad Sci USA (1985) 82:8075-9. doi: 10.1073/ pnas.82.23.8075

19. Nörenberg U, Wille H, Michael Wolff J, Frank R, Rathjen FGG, Norenberg U, et al. The chicken neural extracellular matrix molecule restrictin: similarity with EGF-, fibronectin type III-, and fibrinogen-like motifs. Neuron (1992) 8:849-63. doi: 10.1016/0896-6273(92)90199-N

20. Fuss B, Wintergerst ES, Bartsch U, Schachner M. Molecular characterization and in situ mRNA localization of the neural recognition molecule J1-160/180: A modular structure similar to tenascin. J Cell Biol (1993) 120:1237-50. doi: $10.1083 /$ jcb.120.5.1237

21. Erickson HP, Taylor HC. Hexabrachion proteins in embryonic chicken tissues and human tumors. J Cell Biol (1987) 105:1387-94. doi: 10.1083/ jcb.105.3.1387

22. Erickson HP, Inglesias JL. A six-armed oligomer isolated from cell surface fibronectin preparations. Nature (1984) 311:267-9. doi: 10.1038/311267a0

23. Kammerer RA, Schulthess T, Landwehr R, Lustig A, Fischer D, Engel J. Tenascin-C hexabrachion assembly is a sequential two-step process initiated by coiled-coil $\alpha$-helices. J Biol Chem (1998) 273:10602-8. doi: 10.1074/ jbc.273.17.10602

24. Erickson HP. Tenascin-C, tenascin-R and tenascin-X: a family of of talented proteins in search of functions. Curr Opin Cell Biol (1993) 5:869-76. doi: 10.1016/0955-0674(93)90037-Q

25. Woodworth A, Pesheva P, Fiete D, Baenziger JU. Neuronal-specific Synthesis and Glycosylation of Tenascin-R. J Biol Chem (2004) 279:10413-21. doi: 10.1074/jbc.M312466200

26. Bristow J, Meng Kian T, Gitelman SE, Mellon SH, Miller WL. Tenascin-X: A novel extracellular matrix protein encoded by the human XB gene overlapping P450c21B. J Cell Biol (1993) 122:265-78. doi: 10.1083/jcb.122.1.265

27. Erickson HP. Evolution of the tenascin family-implications for function of the C-terminal fibrinogen-like domain. Perspect Dev Neurobiol (1994) 2:9-19. doi: 10.1080/0907676x.1994.9961218

28. Jones FS, Jones PL. The tenascin family of ECM glycoproteins: Structure, function, and regulation during embryonic development and tissue remodeling. Dev Dyn (2000) 218:235-59. doi: 10.1002/(SICI)1097-0177 (200006)218:2<235::AID-DVDY2>3.0.CO;2-G

29. Volkmer H, Zacharias U, Nörenberg U, Rathjen FG. Dissection of complex molecular interactions of neurofascin with axonin- 1, F11, and tenascin-R, which promote attachment and neurite formation of tectal cells. J Cell Biol (1998) 142:1083-93. doi: 10.1083/jcb.142.4.1083

30. Schumacher S, Volkmer H, Buck F, Otto A, Tarnok A, Roth S, et al. Chicken acidic leucine-rich EGF-like domain containing brain protein (CALEB), a neural member of the EGF family of differentiation factors, is implicated in neurite formation. J Cell Biol (1997) 136:895-906. doi: 10.1083/jcb.136.4.895

31. Schumacher S, Jung M, Nörenberg U, Dorner A, Chiquet-Ehrismann R, Stuermer CAO, et al. CALEB Binds via Its Acidic Stretch to the Fibrinogenlike Domain of Tenascin-C or Tenascin-R and Its Expression Is Dynamically Regulated after Optic Nerve Lesion. J Biol Chem (2001) 276:7337-45. doi: 10.1074/jbc.M007234200

32. Juttner R, More MI, Das D, Babich A, Meier J, Henning M, et al. Impaired synapse function during postnatal development in the absence of CALEB, an EGF-like protein processed by neuronal activity. Neuron (2005) 46:233-45. doi: 10.1016/j.neuron.2005.02.027

33. Jüttner R, Montag D, Craveiro RBB, Babich A, Vetter P, Rathjen FG. Impaired presynaptic function and elimination of synapses at premature stages during postnatal development of the cerebellum in the absence of CALEB (CSPG5/ neuroglycan C). Eur J Neurosci (2013) 38:3270-80. doi: 10.1111/ejn.12313

34. Pintér A, Hevesi Z, Zahola P, Alpár A, Hanics J. Chondroitin sulfate proteoglycan-5 forms perisynaptic matrix assemblies in the adult rat cortex. Cell Signal (2020) 74:109710. doi: 10.1016/j.cellsig.2020.109710

35. Brümmendorf T, Hubert M, Treubert U, Leuschner R, Tarnok A, Rathjen FG. The axonal recognition molecule $\mathrm{F} 11$ is a multifunctional protein: specific domains mediate interactions with $\mathrm{Ng}-\mathrm{CAM}$ and restrictin. Neuron (1993) 10:711-27. doi: 10.1016/0896-6273(93)90172-N

36. Norenberg U, Hubert M, Brummendorf T, Tarnok A, Rathjen FG. Characterization of functional domains of the tenascin- $\mathrm{R}$ (restrictin) polypeptide: Cell attachment site, binding with F11, and enhancement of
F11- mediated neurite outgrowth by tenascin-R. J Cell Biol (1995) 130:473-48. doi: $10.1083 /$ jcb.130.2.473

37. Liao H, Huang W, Schachner M, Guan Y, Guo J, Yan J, et al. $\beta 1$ integrinmediated effects of tenascin-R domains EGFL and FN6-8 on neural stem/ progenitor cell proliferation and differentiation in vitro. J Biol Chem (2008) 283:27927-36. doi: 10.1074/jbc.M804764200

38. Yamaguchi Y. Lecticans: Organizers of the brain extracellular matrix. Cell Mol Life Sci (2000) 57:276-89. doi: 10.1007/PL00000690

39. Xiao ZC, Bartsch U, Margolis RK, Rougon G, Montag D, Schachner M. Isolation of a tenascin- $\mathrm{R}$ binding protein from mouse brain membranes: A phosphacan-related chondroitin sulfate proteoglycan. J Biol Chem (1997) 272:32092-101. doi: 10.1074/jbc.272.51.32092

40. Lundell A, Olin AI, Mörgelin M, Al-Karadaghi S, Aspberg A, Logan DT. Structural basis for interactions between tenascins and lectican C-type lectin domains: Evidence for a crosslinking role for tenascins. Structure (2004) 12:1495-506. doi: 10.1016/j.str.2004.05.021

41. Aspberg A, Binkert C, Ruoslahti E. The versican C-type lectin domain recognizes the adhesion protein tenascin-R. Proc Natl Acad Sci USA (1995) 92:10590-4. doi: 10.1073/pnas.92.23.10590

42. Aspberg A, Miura R, Bourdoulous S, Shimonaka M, Heinegård D, Schachner M, et al. The C-type lectin domains of lecticans, a family of aggregating chondroitin sulfate proteoglycans, bind tenascin-R by protein-protein interactions independent of carbohydrate moiety. Proc Natl Acad Sci USA (1997) 94:1011621. doi: 10.1073/pnas.94.19.10116

43. Margolis RK, Rauch U, Maurel P, Margolis RU. Neurocan and phosphacan: two major nervous tissue-specific chondroitin sulfate proteoglycans. Perspect Dev Neurobiol (1996) 3:273-90.

44. Okuda H, Tatsumi K, Morita S, Shibukawa Y, Korekane H, Horii-Hayashi N, et al. Chondroitin sulfate proteoglycan tenascin- $\mathrm{R}$ regulates glutamate uptake by adult brain astrocytes. J Biol Chem (2014) 289:2620-31. doi: 10.1074/ jbc.M113.504787

45. Becker T, Anliker B, Becker CG, Taylor J, Schachner M, Meyer RL, et al. Tenascin- $\mathrm{R}$ inhibits regrowth of optic fibers in vitro and persists in the optic nerve of mice after injury. Glia (2000) 29:330-46. doi: 10.1002/(SICI)10981136(20000215)29:4<330::AID-GLIA4>3.0.CO;2-L

46. Lochter A, Taylor J, Fuss B, Schachner M. The Extracellular Matrix Molecule Janusin Regulates Neuronal Morphology in a Substrate- and Culture Timedependent Manner. Eur J Neurosci (1994) 6:597-606. doi: 10.1111/j.14609568.1994.tb00304.x

47. Taylor J, Pesheva P, Schachner M. Influence of janusin and tenascin on growth cone behavior in vitro. J Neurosci Res (1993) 35:347-62. doi: 10.1002/ jnr.490350402

48. Pesheva P, Gloor S, Schachner M, Probstmeier R. Tenascin-R is an intrinsic autocrine factor for oligodendrocyte differentiation and promotes cell adhesion by a sulfatide-mediated mechanism. J Neurosci (1997) 17:4642-51. doi: 10.1523/jneurosci.17-12-04642.1997

49. Pesheva P, Gennarini G, Goridis C, Schachner M. The F3/11 cell adhesion molecule mediates the repulsion of neurons by the extracellular matrix glycoprotein J1-160/180. Neuron (1993) 10:69-82. doi: 10.1016/0896-6273 (93) $90243-\mathrm{K}$

50. Xiao ZC, Taylor J, Montag D, Rougon G, Schachner M. Distinct effects of recombinant tenascin- $\mathrm{R}$ domains in neuronal cell functions and identification of the domain interacting with the neuronal recognition molecule F3/11. Eur J Neurosci (1996) 8:766-82. doi: 10.1111/j.1460-9568.1996.tb01262.x

51. Pesheva P, Probstmeier R, Skubitz APN, McCarthy JB, Furcht LT, Schachner M. Tenascin-R (J1 160/180) inhibits fibronectin-mediated cell adhesion functional relatedness to tenascin-C. J Cell Sci (1994) 107:2323-33.

52. Zacharias U, Nörenberg U, Rathjen FG. Functional interactions of the immunoglobulin superfamily member F11 are differentially regulated by the extracellular matrix proteins tenascin-R and tenascin-C. J Biol Chem (1999) 274:24357-65. doi: 10.1074/jbc.274.34.24357

53. Yang H, Xiao ZC, Becker B, Hillenbrand R, Rougon G, Schachner M. Role for myelin-associated glycoprotein as a functional tenascin-R receptor. J Neurosci Res (1999) 55:687-701. doi: 10.1002/(SICI)1097-4547(19990315)55:6<687:: AID-JNR4>3.0.CO;2-6

54. Angelov DN, Walther M, Streppel M, Guntinas-Lichius O, Neiss WF, Probstmeier $\mathrm{R}$, et al. Tenascin- $\mathrm{R}$ is antiadhesive for activated microglia that induce downregulation of the protein after peripheral nerve injury: A new role 
in neuronal protection. J Neurosci (1998) 18:6218-29. doi: 10.1523/ jneurosci.18-16-06218.1998

55. Wintergerst ES, Rathjen FG, Schwaller B, Eggli P, Celio MR. Tenascin-R associates extracellularly with parvalbumin immunoreactive neurones but is synthesised by another neuronal population in the adult rat cerebral cortex. J Neurocytol (2001) 30:293-301. doi: 10.1023/A:1014452212067

56. Wintergerst ES, Fuss B, Bartsch U. Localization of Janusin mRNA in the Central Nervous System of the Developing and Adult Mouse. Eur J Neurosci (1993) 5:299-310. doi: 10.1111/j.1460-9568.1993.tb00497.x

57. Dauth S, Grevesse T, Pantazopoulos H, Campbell PH, Maoz BM, Berretta S, et al. Extracellular matrix protein expression is brain region dependent. J Comp Neurol (2016) 524:1309-36. doi: 10.1002/cne.23965

58. Probstmeier R, Nellen J, Gloor S, Wernig A, Pesheva P. Tenascin-R is expressed by Schwann cells in the peripheral nervous system. J Neurosci Res (2001) 64:70-8. doi: 10.1002/jnr.1055

59. Bruckner G, Grosche J, Schmidt S, Hartig W, Margolis RU, Delpech B, et al. Postnatal development of perineuronal nets in wild-type mice and in a mutant deficient in tenascin-R. JComp Neurol (2000) 428:616-29. doi: 10.1002/10969861(20001225)428:4<616::AID-CNE3>3.0.CO;2-K

60. Hagihara K, Miura R, Kosaki R, Berglund E, Ranscht B, Yamaguchi Y. Immunohistochemical evidence for the brevican-tenascin- $\mathrm{R}$ interaction: Colocalization in perineuronal nets suggests a physiological role for the interaction in the adult rat brain. J Comp Neurol (1999) 410:256-64. doi: 10.1002/(SICI)1096-9861(19990726)410:2<256::AID-CNE7>3.0.CO;2-5

61. Celio MR, Spreafico R, De Biasi S, Vitellaro-Zuccarello L. Perineuronal nets: Past and present. Trends Neurosci (1998) 21:510-5. doi: 10.1016/S0166-2236(98)01298-3

62. Reichelt AC, Hare DJ, Bussey TJ, Saksida LM. Perineuronal Nets: Plasticity, Protection, and Therapeutic Potential. Trends Neurosci (2019) 42:458-70. doi: $10.1016 /$ j.tins.2019.04.003

63. Berardi N, Pizzorusso T, Ratto GM, Maffei L. Molecular basis of plasticity in the visual cortex. Trends Neurosci (2003) 26:369-78. doi: 10.1016/S0166-2236 (03)00168-1

64. Haunsoø A, Ibrahim M, Bartsch U, Letiembre M, Celio MR, Menoud PA. Morphology of perineuronal nets in tenascin-R and parvalbumin single and double knockout mice. Brain Res (2000) 864:142-5. doi: 10.1016/S0006-8993 (00)02173-9

65. Weber P, Bartsch U, Rasband MN, Czaniera R, Lang Y, Bluethmann H, et al. Mice deficient for tenascin-R display alterations of the extracellular matrix and decreased axonal conduction velocities in the CNS. J Neurosci (1999) 19:4245-62. doi: 10.1523/jneurosci.19-11-04245.1999

66. Nikonenko A, Schmidt S, Skibo G, Brückner G, Schachner M. Tenascin-Rdeficient mice show structural alterations of symmetric perisomatic synapses in the CA1 region of the hippocampus. J Comp Neurol (2003) 456:338-49. doi: 10.1002/cne.10537

67. Saghatelyan AK, Dityatev A, Schmidt S, Schuster T, Bartsch U, Schachner M. Reduced perisomatic inhibition, increased excitatory transmission, and impaired long-term potentiation in mice deficient for the extracellular matrix glycoprotein tenascin-R. Mol Cell Neurosci (2001) 17:226-40. doi: 10.1006/mcne.2000.0922

68. Murai KK, Misner D, Ranscht B. Contactin supports synaptic plasticity associated with hippocampal long-term depression but not potentiation. Curr Biol (2002) 12:181-90. doi: 10.1016/S0960-9822(02)00680-2

69. Bukalo O, Schachner M, Dityatev A. Hippocampal metaplasticity induced by deficiency in the extracellular matrix glycoprotein tenascin-R. $J$ Neurosci (2007) 27:6019-28. doi: 10.1523/JNEUROSCI.1022-07.2007
70. Montag-Sallaz M, Montag D. Severe cognitive and motor coordination deficits in tenascin-R-deficient mice. Genes Brain Behav (2003) 2:20-31. doi: 10.1034/ j.1601-183X.2003.00003.X

71. Bartsch U, Pesheva P, Raff M, Schachner M. Expression of janusin (J1-160/ $180)$ in the retina and optic nerve of the developing and adult mouse. Glia (1993) 9:57-69. doi: 10.1002/glia.440090108

72. Czopka T, Von Holst A, Schmidt G, Ffrench-Constant C, Faissner A, Tenascin C. and tenascin R similarly prevent the formation of myelin membranes in a RhoA-dependent manner, but antagonistically regulate the expression of myelin basic protein via a separate pathway. Glia (2009) 57:1790-801. doi: 10.1002/glia.20891

73. Xiao ZC, Ragsdale DS, Malhotra JD, Mattei LN, Braun PE, Schachner M, et al. Tenascin- $\mathrm{R}$ is a functional modulator of sodium channel $\beta$ subunits. J Biol Chem (1999) 274:26511-7. doi: 10.1074/jbc.274.37.26511

74. Srinivasan J, Schachner M, Catterall WA. Interaction of voltage-gated sodium channels with the extracellular matrix molecules tenascin-C and tenascin-R. Proc Natl Acad Sci USA (1998) 95:15753-7. doi: 10.1073/ pnas. 95.26 .15753

75. David LS, Schachner M, Saghatelyan A. The extracellular matrix glycoprotein tenascin- $\mathrm{R}$ affects adult but not developmental neurogenesis in the olfactory bulb. J Neurosci (2013) 33:10324-39. doi: 10.1523/ JNEUROSCI.5728-12.2013

76. Saghatelyan A, De Chevigny A, Schachner M, Lledo PM. Tenascin-R mediates activity-dependent recruitment of neuroblasts in the adult mouse forebrain. Nat Neurosci (2004) 7:347-56. doi: 10.1038/nn1211

77. Xu JC, Xiao MF, Jakovcevski I, Sivukhina E, Hargus G, Cui YF, et al. The extracellular matrix glycoprotein tenascin- $\mathrm{R}$ regulates neurogenesis during development and in the adult dentate gyrus of mice. J Cell Sci (2014) 127:64152. doi: $10.1242 /$ jcs. 137612

78. Hargus G, Cui Y, Schmid J-S, Xu J, Glatzel M, Schachner M, et al. Tenascin-R promotes neuronal differentiation of embryonic stem cells and recruitment of host-derived neural precursor cells after excitotoxic lesion of the mouse striatum. Stem Cells (2008) 26:1973-84. doi: 10.1634/stemcells.2007-0929

79. Wagner M, Lévy J, Jung-Klawitter S, Bakhtiari S, Monteiro F, Maroofian R, et al. Loss of TNR causes a nonprogressive neurodevelopmental disorder with spasticity and transient opisthotonus. Genet Med (2020) 22:1061-8. doi: 10.1038/s41436-020-0768-7

80. Dufresne D, Hamdan FF, Rosenfeld JA, Torchia B, Rosenblatt B, Michaud JL, et al. Homozygous deletion of Tenascin- $\mathrm{R}$ in a patient with intellectual disability. J Med Genet (2012) 49:451-4. doi: 10.1136/jmedgenet-2012-100831

81. Lynch DS, Rodrigues Brandão De Paiva A, Zhang WJ, Bugiardini E, Freua F, Tavares Lucato L, et al. Clinical and genetic characterization of leukoencephalopathies in adults. Brain (2017) 140:1204-11. doi: 10.1093/ brain/awx045

Conflict of Interest: The authors declare that the research was conducted in the absence of any commercial or financial relationships that could be construed as a potential conflict of interest.

Copyright (๑) 2021 Rathjen and Hodge. This is an open-access article distributed under the terms of the Creative Commons Attribution License (CC BY). The use, distribution or reproduction in other forums is permitted, provided the original author(s) and the copyright owner(s) are credited and that the original publication in this journal is cited, in accordance with accepted academic practice. No use, distribution or reproduction is permitted which does not comply with these terms. 